\title{
KELIMPAHAN JENIS TERIPANG DI PERAIRAN TERBUKA \\ DAN PERAIRAN TERTUTUP PULAU PANJANG JEPARA, JAWA TENGAH
}

\author{
Guliano Gema Adi Satria, Bambang Sulardiono ${ }^{l}$, Frida Purwanti \\ Program Studi Manajemen Sumberdaya Perairan, Jurusan Perikanan \\ Fakultas Perikanan dan Ilmu Kelautan, Universitas Dipenogoro
}

\begin{abstract}
ABSTRAK
Perairan terbuka adalah suatu daerah perairan yang menghadap ke arah laut lepas tanpa adanya penghalang baik itu pulau maupun daratan di depannya sehingga perairan terbuka sangat dipengaruhi oleh ombak dan gelombang. Perairan tertutup adalah suatu perairan yang terhalang oleh daratan atau pulau di depannya atau berupa teluk, sehingga kekuatan arus dan gelombang akan berkurang ketika sampai di pantai. Teripang merupakan salah satu spesies yang memiliki nilai ekonomis tinggi dan banyak dilakukan penangkapan terhadap teripang yang menyebabkan menurunnya populasi teripang pada suatu perairan. Tujuan penelitian ini adalah untuk mengetahui kelimpahan teripang pada perairan terbuka dan perairan tertutup Pulau Panjang, Jepara. Metode yang digunakan adalah metode kuadran transek berukuran $2 \times 2$ meter, yang diletakkan pada line transek sepanjang 100 meter. Pengambilan sampel dilakukan sebanyak tiga kali pada setiap titik pengamatan, dengan jarak antara setiap line 10 meter. Jenis teripang yang ditemukan pada perairan terbuka dan tertutup pulau Panjang adalah Holothuria atra, H.leucospilota, dan H.scabra. Dimana kelimpahan teripang pada perairan terbuka pulau panjang adalah 72 individu $/ 1200 \mathrm{~m}^{2}$ pada jenis H.atra, 36 individu/1200m ${ }^{2}$ pada jenis H.Leucospilota, 1 individu/ $1200 \mathrm{~m}^{2}$ pada jenis H.scabra. Sedangkan kelimpahan jenis teripang pada perairan tertutup pulau Panjang adalah 37 individu/ $1200 \mathrm{~m}^{2}$ pada jenis H.atra dan 22 individu/ $1200 \mathrm{~m}^{2}$ pada jenis H.Leucospilota.
\end{abstract}

Kata Kunci: Teripang, Kelimpahan, Perairan Terbuka dan Perairan Tertutup.

\section{ABSTRACT}

Open water is a water area facing the open sea without a barrier either the island or the mainland in front of it, so it is strongly influenced by waves and current. Closed water are water blocked by a mainland or island in front of it or a bay, so the strength of currents and waves will be reduced when it reached the coast. Sea cucumber is a species that have high economical value and have been catched so the population in the waters is decreasing. This study aims to determine the abundance of sea cucumber species in the open and closed waters of Panjang Island, Jepara. The method used in this study was using quadrant transect sized $2 \times 2$ meters, which is placed on the line transect along 100 meters. Sampling was performed three times at each observation point, the distance between each line is 10 meters. Sea cucumber species found in the open waters and closed waters of Panjang Island are Holothuria atra, H. leucospilota, and H.scabra. abundance in the open waters of Panjang Island are 72 individuals $/ 1200 \mathrm{~m}^{2}$ for H.atra, 36 individuals $/ 1200 \mathrm{~m}^{2}$ for H.leucospilota, 1 individuals $/ 1200 \mathrm{~m}^{2}$ for H.scabra. whereas abundance in the closed waters of Panjang Island are 37 individuals $/ 1200 \mathrm{~m}^{2}$ for H.atra, 22 individuals $/ \mathrm{m}^{2}$ for H.leucospilota.

Keywords: Sea Cucumber, Abundance, Open and Closed Waters.

*Penulis Penangggung jawab 


\section{A. Pendahuluan}

Laut mempunyai potensi yang sangat besar sebagai penyedia sumber bahan makanan bagi manusia. Laut merupakan habitat dari berbagai hewan dan tumbuhan yang mempunyai peran dan fungsi masing-masing. Sejak awal peradaban manusia, laut telah banyak digunakan sebagai tempat mendapatkan makanan maupun keperluan lainnya. Berbagai jenis hewan laut diburu untuk memenuhi kebutuhan tersebut. Teripang telah lama menjadi komoditas perdagangan. Harga teripang dari tahun ke tahun terus melonjak dan harganya sangat ditentukan oleh ukuran dan kualitas hasil olahannya. Penangkapan dan perdagangan teripang di Indonesia di perkirakan telah berlangsung sejak adanya hubungan dagang antara masyarakat Nusantara dan bangsa Cina sekitar tahun 1700-an (Kordi, 2010).

Teripang merupakan hewan yang termasuk dalam Filum Echinodermata dari Kelas Holothuroidea. Habitat hewan ini pada zona intertidal sampai kedalaman 20 meter dan substrat berpasir yang berasosiasi dengan ekosistem terumbu karang dan lamun. Fungsi ekologis teripang dalam struktur trofik sebagai pemakan suspensi dan detritus serta penyeimbang rantai makanan (Aziz, 1997). Pemangsa teripang umumnya adalah bintang laut berukuran besar, kepiting, dan kelompok gastropoda jenis Tonna perdix (KROPP 1982 dalam Aziz 1995).

Teripang atau timun laut tidak hanya memiliki nilai ekologis tetapi juga nilai ekonomis yang tinggi dalam perikanan karena rasa dan kandungan gizinya yang tinggi. Beberapa jenis teripang yang termasuk dalam kategori komersial terdiri dari Famili Holothuridae dan Stichopodidae. Indonesia dikenal sebagai salah satu negara penghasil teripang untuk memenuhi permintaan dari negara-negara Eropa, Jepang, Singapura, Malaysia, dan Amerika (Aziz, 1997).

Teripang (Holothuroide) merupakan golongan yang paling umum di jumpai. Hewan ini banyak terdapat di paparan terumbu karang kemudian juga di pantai berbatu atau yang berlumpur. Teripang dapat dijumpai tidak hanya di perairan dangkal, ada juga yang hidup di laut dalam, bahkan di palung laut yang terdalam di dunia pun juga diketemukan teripang. Laut banda yang dalamnya sekitar 7.000 meter terdapat teripang Paroriza greview. Di palung jawa yang juga dalamnya sekitar 7.000 meter ditemukan antara lain teripang Periamna naresi dan Elpidia sundensis (Nontji, 2005).

Pulau Panjang merupakan sebuah pulau yang terletak sekitar 1 mil dari Pantai Kartini Jepara. Pulau Panjang memiliki luas 19 hektar. Pulau ini memiliki potensi keanekaragaman hayati seperti terumbu karang, lamun dan asosiasi biota contohnya teripang. Potensi keanekaragaman hayati tersebut menarik minat banyak wisatawan untuk datang berkunjung yang dapat menyebabkan semakin menurunnya tingkat keanekaragaman hayati pulau tersebut, yang juga berpengaruh terhadap kelimpahan dari asosiasi biota disekitar Pulau Panjang.

Tujuan dilakukannya penelitian ini adalah sebagai berikut:

1. Untuk mengetahui kelimpahan jenis teripang yang terdapat pada perairan terbuka Pulau Panjang;

2. Untuk mengetahui kelimpahan jenis teripang yang terdapat pada perairan tertutup Pulau Panjang.

\section{B. Materi dan Metode Penelitian}

1. Materi Penelitian

Materi yang digunakan pada penelitian ini adalah teripang yang ditemukan di perairan terbuka dan perairan tertutup Pulau Panjang Jepara. Alat yang digunakan dalam penelitian ini yaitu Masker Snorkel digunakan untuk alat bantu di bawah air. Roll Meter digunakan sebagai line transek. Kuadran Transek digunakan untuk pengambilan data kelimpahan teripang. Secchi disc digunakan untuk mengukur kecerahan. Termometer air raksa digunakan untuk mengukur suhu permukaan laut dan suhu udara. Refraktometer digunakan untuk mengukur salinitas. Current meter digunakan untuk mengukur arus. GPS (Global Positioning System) digunakan untuk penentuan plot sampling.

\section{Metode Penelitian}

Metode yang digunakan dalam pengambilan data kelimpahan teripang adalah sebagai berikut:

a. Observasi (survey) lapangan untuk menentukan lokasi sampling;

b. Plotting GPS;

c. Memasang line transek yang telah ditandai dengan skala sepanjang 100 meter sejajar garis pantai;

d. Memasang kuadran transek berukuran 2 x 2 meter yang diletakkan pada bagian kanan line transek; dan

e. Mengambil data kelimpahan teripang di dalam frame kuadran transek berukuran $2 \times 2$ meter sepanjang 100 meter. 
1. Suhu

Pengukuran suhu dalam penelitian ini dilakukan dengan menggunakan 2 buah thermometer air raksa dengan ketelitian $1{ }^{\circ} \mathrm{C}$. 1 buah thermometer digunakan untuk mengukur suhu udara, sedangkan 1 buah thermometer yang lain digunakan untuk mengukur suhu air.

2. Salinitas

Salinitas perairan dapat diukur menggunakan refraktometer yang dalam penggunaannya meneteskan air yang akan diukur salinitasnya pada ujung alat tersebut, kemudian melihat nilai skala salinitas yang tertera pada refraktometer.

3. Kecerahan

Pengukuran kecerahan badan air menggunakan alat yang dinamakan secchi disc. Alat ini berbentuk piringan yang terbuat dari seng atau pun besi yang dicat dengan warna hitam dan putih yang diikatkan pada tali atau tambang berskala.

4. Kedalaman

Kedalaman perairan di lokasi penelitian diukur dengan menggunakan tali atau tambang berskala dengan ketelitian $1 \mathrm{~cm}$.

5. Kecepatan arus

Kecepatan arus dapat diukur dengan menggunakan curent meter yang dalam penggunaannya adalah dengan mengapungkan alat ini di permukaan air dan mencatat jumlah putaran kipas yang terdapat pada alat ini.

6. $\mathrm{pH}$ atau derajat keasaman

$\mathrm{pH}$ atau derajat keasaman perairan yang diukur dalam penelitian ini menggunakan $\mathrm{pH}$ paper.

\section{Metode Analisis Data}

Kelimpahan Teripang ( Holothuroidea ) dihitung dengan menggunakan rumus dalam Odum (1993), yaitu:

Keterangan:

$$
\mathrm{KR}=\frac{n i}{N} \times 100 \%
$$

$$
\begin{array}{ll}
\text { KR } & \text { : Kerapatan Relatif } \\
\text { ni } & \text { : Jumlah Individu } \\
\mathrm{N} & \text { : Jumlah total individu }
\end{array}
$$

Keanekaragaman spesies dapat dikatakan sebagai indikasi banyaknya jenis makrobenthos dan bagaimana penyebaran jumlah individu pada setiap jenis dan lokasi sampling. Untuk menentukan keanekaragaman dihitung dengan menggunakan formula Shannon-Weaver (Odum, 1993) berikut:

\section{Keterangan:}

$$
H^{\prime}=-\sum_{i=1}^{i} \mathrm{Pi} \ln \mathrm{Pi}
$$

$$
\begin{array}{lll}
\mathrm{H}^{\prime} & \text { : Indeks Keanekaragaman Jenis } & \mathrm{S}: \text { Jumlah Genus penyusun Komunitas } \\
\mathrm{ni} & \text { : Jumlah individu jenis ke-i } & \mathrm{Pi}: \mathrm{ni} / \mathrm{N} \\
\mathrm{N} & \text { : Jumlah total individu } &
\end{array}
$$

Tabel 2. Kisaran stabilitas perairan berdasarkan indeks keanekaragaman

\begin{tabular}{lll}
\hline No. & Kisaran stabilitas & Keanekaragaman \\
\hline 1. & $0<\mathrm{H}^{\prime} \leq 1$ & Rendah (tidak stabil) \\
2. & $1<\mathrm{H}^{\prime} \leq 3$ & Sedang \\
3. & $\mathrm{H}^{\prime}>3$ & Tinggi (stabil) \\
\hline
\end{tabular}

Keseragaman dapat dikatakan sebagai keseimbangan, yaitu komposisi individu tiap jenis yang terdapat dalam suatu komunitas. Untuk menghitung keseragaman jenis dapat dihitung menggunakan rumus Evennes (Odum, 1993), yaitu:

$$
\mathbf{e}=\frac{H z}{H \max }
$$




\section{Keterangan:}

e : Indeks keseragaman $\quad H^{\prime} \quad$ : Indeks keanekaragaman

$\mathrm{H}$ max : Keanekaragaman spesies maksimum $(\ln \mathrm{S})$

Dimana:

e $<0,4 \quad$ : Tingkat keseragaman populasi kecil

$0,4<\mathrm{e}<0,6$ : Tingkat keseragaman populasi sedang

$0,6<\mathrm{e}<1 \quad$ : Tingkat keseragaman populasi besar

Untuk menghitung indeks dominansi digunakan rumus odum (1993) sebagai berikut:

$$
\mathbf{D}=(\mathbf{n i} / \mathbf{N})^{2}
$$

Keterangan :

D : Indeks dominansi

ni : Jumlah individu spesies ke-i

$\mathrm{N} \quad$ : Jumlah total spesies

Dimana :

$0<\mathrm{D}<0,6$ : Tidak terdapat spesies yang mendominasi

$0,6<\mathrm{D}<1 \quad$ : Terdapat spesies yang mendominasi

\section{Hasil dan Pembahasan}

1. Hasil

a. Deskripsi lokasi

Penelitian dilakukan di perairan pulau Panjang, Jepara, Jawa Tengah. Secara geografis perairan pulau Panjang terletak pada titik koordinat $06^{\circ} 34^{\prime \prime} 30^{\prime} \mathrm{LS}, 110^{\circ} 37^{\prime \prime} 34^{\prime} \mathrm{BT}$. Adapun batas-batas wilayah pulau Panjang ini adalah sebagai berikut:

1. Sebelah utara berbatasan dengan Laut Jawa, Karimun Jawa

2. Sebelah selatan berbatasan dengan Laut Jawa

3. Sebelah timur berbatasan dengan Laut Jawa

4. Sebelah barat berbatasan dengan Teluk Awur, Kecamatan Jepara

Penelitian ini dilakukan di wilayah perairan pulau Panjang yang merupakan pulau kecil terletak 1,5 mil sebelah barat kota Jepara dan dapat ditempuh selama 10 - 20 menit dari pantai Kartini, Jepara (Dinas Pariwisata dan Kebudayaan Jepara, 2011).

Pulau Panjang merupakan pulau berpantai landai dan berpasir putih yang dikelilingi ekosistem terumbu karang dan ekosistem lamun. Ekosistem karang di sisi selatan Pulau Panjang lebih berkembang dibandingkan dengan sisi lainnya, sedangkan ekosistem lamun lebih berkembang pada sisi timur dari pulau Panjang. Pulau Panjang seharusnya memiliki potensi terhadap keanekaragaman hayati. Dengan adanya berbagai macam aktivitas manusia seperti kegiatan wisata dan kegiatan penangkapan menyebabkan semakin menurunnya potensi keanekaragaman hayati dari pulau panjang dalam hal ini jumlah biota laut teripang. Titik koordinat dari titik sampling yang dilakukan di Perairan Terbuka adalah $6^{\circ} 34^{\prime} 35.45^{\prime \prime} \mathrm{S}$ dan $110^{\circ} 37^{\prime} 52.55^{\prime \prime} \mathrm{E}$ dan di perairan tertutup adalah $6^{\circ} 34^{\prime} 40.56^{\prime \prime} \mathrm{S}$ dan $110^{\circ} 37^{\prime} 44.83^{\prime \prime} \mathrm{E}$.

\section{b. Jenis Teripang yang Ditemukan Pada Lokasi Sampling}

Jenis teripang yang ditemukan pada setiap stasiun pengamatan bervariasi jumlah spesiesnya dan yang ditemukan hanya terdapat 3 jenis teripang, jenis dan jumlah teripang yang ditemukan pada tiap stasiun penelitian yaitu stasiun A perairan terbuka dan stasiun B perairan tertutup tersaji dalam Tabel 3 berikut :

Tabel 3. Jenis Teripang di Lokasi Penelitian (Individu/1200 meter ${ }^{2}$ )

\begin{tabular}{llcccc}
\hline & & \multicolumn{3}{c}{ Stasiun } \\
\cline { 3 - 6 } No & \multirow{2}{*}{ Spesies } & 1 & $\mathrm{~A}$ & \multicolumn{3}{c}{$\mathrm{B}$} \\
\cline { 3 - 6 } & & 57 & 15 & 12 & 2 \\
\hline 1 & H.atra & 0 & 36 & 0 & 22 \\
2 & H.leucospilota & 0 & 1 & 0 & 0 \\
3 & H.scabra & 57 & 52 & 12 & 47 \\
\hline
\end{tabular}

Sumber : Data Penelitian 2013 


\section{c. Kelimpahan teripang}

Kelimpahan jenis teripang yang ditemukan selama penelitian pada tiap-tiap stasiun yaitu stasiun A perairan terbuka dan stasiun B perairan tertutup tersaji pada Tabel 4 berikut ini :

Tabel 4. Kelimpahan Jenis Teripang di Lokasi Penelitian (Individu/1200 meter $^{2}$ )

\begin{tabular}{|c|c|c|c|c|c|}
\hline \multirow{3}{*}{ No. } & \multirow{3}{*}{ Spesies } & \multicolumn{4}{|c|}{ Stasiun } \\
\hline & & \multicolumn{2}{|c|}{$\mathrm{A}$} & \multicolumn{2}{|c|}{$\mathrm{B}$} \\
\hline & & $\mathrm{KI}$ & $\mathrm{KR}(\%)$ & KI & $\mathrm{KR}(\%)$ \\
\hline 1. & H.atra & 72 & 65,74 & 37 & 62,71 \\
\hline 2. & H.leucospilota & 36 & 33,33 & 22 & 37,29 \\
\hline 3. & H.scabra & 1 & 0,93 & 0 & 0 \\
\hline & Jumlah & 109 & 100 & 59 & 100 \\
\hline
\end{tabular}

Keterangan : $\mathrm{KI}=$ Kelimpahan Individu $\mathrm{KR}=$ Kelimpahan Relatif

Sumber : Data Penelitian 2013

\section{d. Indeks Keanekaragaman (H') dan Indeks Keseragaman (e) Teripang}

Nilai Indeks Keanekaragaman dan Indeks Keseragaman teripang pada setiap lokasi penelitian dipengaruhi oleh jumlah individu setiap jenis maupun jumlah seluruh jenis. Hasil pengukuran Nilai Indeks Keanekaragaman dan Keseragaman pada masing-masing lokasi selama penelitian tersaji pada Tabel 5 berikut :

Tabel 5. Nilai Keanekaragaman (H') dan Indeks Keseragaman (e) Teripang

\begin{tabular}{cccc}
\hline No. & Stasiun & H'$^{\prime}$ & E \\
\hline 1. & A & 0,68 & 0,22 \\
2. & B & 0,66 & 0,22 \\
\hline
\end{tabular}

Sumber : Data Penelitian 2013

e. Parameter Kualitas Air

Berdasarkan hasil pengamatan yang dilakukan pada tiap-tiap stasiun, hasil dari parameter fisika dan parameter kimia perairan yang diukur selama penelitian secara lengkap dapat dilihat pada Tabel 6 berikut ini :

Tabel 6. Parameter Kualitas Air Pada Lokasi Penelitian

\begin{tabular}{lccccc}
\hline & & \multicolumn{4}{c}{ Stasiun } \\
\cline { 3 - 6 } No & Parameter & \multicolumn{3}{c}{$\mathrm{A}$} & \multicolumn{3}{c}{$\mathrm{B}$} \\
\cline { 3 - 6 } & & 29,76 & 29,76 & 29,09 & 30,09 \\
\hline 1 & Suhu Air $\left({ }^{0} \mathrm{C}\right)$ & 29,76 & 28,76 & 29,18 & 28,09 \\
2 & Suhu Udara $\left({ }^{0} \mathrm{C}\right)$ & $0,88-1,05$ & $0,60-083$ & $0,41-0,76$ & $0,64-0,85$ \\
3 & Kedalaman $(\mathrm{m})$ & 0 & 0 & 0 & 0 \\
4 & Kecerahan $(\mathrm{m})$ & 29,76 & 30,09 & 29,76 & 30,09 \\
5 & Salinitas $(\% \circ)$ & 6,58 & 7,05 & 6,58 & 7,05 \\
6 & pH & 0,53 & 0,72 & 0,49 & 0,67 \\
7 & Arus $(\mathrm{m} / \mathrm{s})$ & &
\end{tabular}

Sumber : Data Penelitian 2013

\section{Pembahasan}

\section{a. Jenis Teripang yang Ditemukan}

Dari hasil penelitian jenis teripang yang ditemukan pada stasiun A dan B terdiri dari 3 jenis teripang yaitu jenis $H$. atra, H. leucospilota dan H. scabra. Pada stasiun A terdapat dua titik pengamatan yaitu titik 1 dan titik 2. Pada titik 1 hanya ditemukan jenis H.atra, pada titik 2 ditemukan 3 jenis teripang yaitu H.atra, H.leucospilota, H.scabra. Titik 1 memiliki substrat berupa pasir dan ditumbuhi oleh tumbuhan lamun, titik 2 memiliki substrat yang berupa pasir yang tertutupi pecahan karang, dan karang hidup. Teripang yang ditemukan pada titik 1 terletak di antara tumbuhan lamun, dan teripang yang ditemukan di titik 2 terletak di antara pecahanpecahan karang dan terdapat pula yang tergeletak di dasar perairan dengan membenamkan diri ke dalam pasir.

Pada stasiun B yang juga memiliki dua titik pengamatan yaitu titik 1 dan titik 2. Pada titik 1 hanya ditemukan jenis H.atra. Pada titik 2 ditemukan 2 jenis teripang yaitu H.atra, dan H.leucospilota. Pada titik 1 memiliki substrat dasar berupa pasir yang tertutupi pecahan karang, teripang yang ditemukan tergeletak di dasar perairan dengan menutupi tubuhnya dengan pasir, pada titik 2 memiliki substrat berupa pasir dan juga masih 
banyak terdapat karang hidup. Teripang yang ditemukan pada titik ini tersembunyi di bawah karang hidup dan membenamkan dirinya kedalam substrat perairan.

Spesies teripang lain yang menurut sumber (penduduk sekitar lokasi penelitian) ada, tetapi tidak ditemukan selama penelitian dimungkinkan karena pada saat sampling penelitian dilakukan pada waktu pagi hari, sedangkan teripang memiliki kecenderungan aktif pada saat malam hari.

\section{b. Kelimpahan Teripang}

Kelimpahan jenis teripang yang ditemukan dari hasil penelitian pada stasiun A adalah jenis H.atra sebanyak 72 individu/1200m ${ }^{2}$, H.leucospilota sebanyak 36 individu/1200m², dan H.scabra sebanyak 1 individu/1200 $\mathrm{m}^{2}$. Pada stasiun B ditemukan jenis H.atra sebanyak 37 individu/m² $\mathrm{m}^{2}$ dan jenis H.leucospilota sebanyak 22 individu $/ 1200 \mathrm{~m}^{2}$. Adapun kelimpahan jenis teripang pada daerah perairan terbuka lebih banyak dibandingkan dengan daerah perairan tertutup, hal ini dapat disebabkan karena adanya perbedaan kuat arus sehingga mempengaruhi parameter fisika kimia lainnya yang berdampak langsung terhadap kehidupan teripang.

Jenis teripang yang paling dominan dan sering ditemukan serta memiliki jumlah yang paling banyak pada adalah jenis H.atra dengan jumlah pada kedua stasiunnya sebanyak 109 individu/1200m² ${ }^{2}$ dan berikutnya adalah H.leucospilota dengan jumlah 58 individu/1200m ${ }^{2}$ dan H.scabra sebanyak 1 individu/1200m ${ }^{2}$.

Berdasarkan jenis jumlah teripang yang ditemukan $H$. atra memiliki jumlah yang paling banyak dan terdapat pada setiap stasiun pengambilan sampel, karena dapat dimungkinkan jenis teripang tersebut tidak banyak diburu oleh nelayan penangkap teripang tidak seperti jenis-jenis teripang lainnya. Hal ini disebabkan karena jenis spesies tersebut tergolong komersial rendah (BTNKj, 2008). Jenis H. leucospilota memiliki jumlah yang lebih sedikit dibandingkan dengan jenis H.atra.

Kelimpahan relatif teripang yang paling tinggi didapat oleh $H$. Atra sebanyak 108 individu dengan kelimpahan relatif sebesar $65,74 \%$ dan $62,71 \%$ sehingga dapat diketahui dari kedua stasiun tersebut yang memiliki kelimpahan yang paling banyak adalah stsaiun A yaitu perairan terbuka, kemudian disusul oleh jenis H. leucospilota dengan jumlah individu sebanyak 58 dengan kelimpahan relatifnya 33,33\% dan 37,29\%, jenis H.scabra memiliki jumlah paling sedikit dibandingkan dengan jenis lain yaitu 1 dengan kelimpahan relatifnya 0,93\%. Menurut Hymann (1995), faktor-faktor lain yang mempengaruhi tinggi rendahnya kelimpahan relatif setiap spesies, di antaranya adalah faktor persaingan antar spesies, hama dan penyakit, dan predator, serta dari faktor manusia, yaitu aktivitas tangkapan nelayan. Spesies yang mempunyai kemampuan untuk mempertahankan diri, maka akan mendapatkan kesempatan untuk tetap hidup dan bertahan pada habitatnya. Demikian juga pada spesies yang merupakan kategori rendah dan bukan merupakan spesies target, maka akan mendapatkan kesempatan untuk tetap hidup pada habitatnya.

\section{c. Indeks Keanekaragaman (H') dan Indeks Keseragaman (e) Teripang}

Berdasarkan hasil penelitian didapatkan indeks keanekaragaman (H') teripang pada stasiun A sebesar 0,68 dan pada stasiun B sebesar 0,66 stasiun C sebesar 0,64, dan stasiun D sebesar 0,68. Indeks keanekaragaman teripang pada semua stasiun termasuk dalam kategori rendah. Jenis teripang yang ditemukan pada lokasi penelitian memiliki jenis yang berbeda yang membuktikan pada lokasi penelitian tersebut terdapat beraneka ragam jenis teripang yang hidup dan berasosiasi di lokasi tersebut. Hal tersebut sesuai dengan pernyataan Poole (1974) dalam Suprapti (1993), bahwa keanekaragaman tidak hanya dilihat dari banyaknya jenis tetapi juga dari penyebaran individu dalam tiap jenisnya dan tergantung dari kelimpahan individu dalam spesies.

Nilai indeks keseragaman teripang pada stasiun A sebesar 0,22 dan B sebesar 0,22. Indeks keseragaman teripang pada setiap stasiun termasuk dalam kategori tingkat keseragaman populasi kecil, Jenis teripang yang ditemukan pada lokasi penelitian termasuk sangat sedikit, hal tersebut yang memungkinkan keseragaman populasi teripang kecil dan persebarannya juga tidak merata.Hal tersebut sesuai dengan pernyataan Wilham dan Dorris (1986), bahwa indeks keanekaragaman akan mencapai maksimum bila kelimpahan individu per jenis menyebar secara merata yang berarti jumlah individu setiap jenisnya relatif sama (seragam). Dikatakan lebih lanjut semakin kecil keseragaman jenis dalam komunitas, artinya penyebaran jumlah individu setiap jenis tidak sama. Ada kecenderungan bahwa komunitas tersebut didominasi oleh sesuatu spesies atau jenis tertentu. Sebaliknya semakin besar nilai indeks keseragaman (menjauhi nol) dalam komunitas akan menyebabkan keseragaman jenis semakin besar, artinya kelimpahan setiap jenis dapat dikatakan sama atau tidak jauh berbeda dan didalam komunitas tersebut tidak dapat didominasi. 


\section{d. Parameter Kualitas Air}

Parameter kualitas air sangat mempengaruhi kondisi habitat lingkungan hidup teripang seperti ekosistem padang lamun dan ekosistem terumbu karang. Parameter kualitas air yang diukur diantaranya suhu air, kedalaman, salinitas, $\mathrm{pH}$, arus dan kecerahan.

Hasil Pengukuran suhu air yaitu pada stasiun A dan stasiun B berkisar antara $29,09^{\circ} \mathrm{C}-30,09^{\circ} \mathrm{C}$. Teripang membutuhkan kisaran suhu perairan yang ideal untuk menunjang kehidupan di dalam ekosistem tempat dimana teripang akan berkembang dengan baik. Menurut Sutaman (1992), bahwa suhu yang baik untuk kehidupan teripang berkisar antara $22^{\circ} \mathrm{C}-32^{\circ} \mathrm{C}$, maka dari hasil pernyataan tersebut, kisaran suhu air pada lokasi penelitian masih sangat ideal untuk menunjang kehidupan teripang. Selain untuk menunjang kehidupan teripang, suhu air juga harus menunjang ekosistem lamun dan terumbu karang, dimana tempat teripang tersebut hidup. Menurut Nybakken (1992), bahwa lamun akan tumbuh baik pada suhu $28-30^{\circ} \mathrm{C}$ dan karang akan tumbuh baik pada suhu $25-29{ }^{\circ} \mathrm{C}$ dan masih memiliki toleransi sampai dengan suhu $40{ }^{\circ} \mathrm{C}$.

Pengukuran salinitas perairan pada lokasi sampling yaitu pada stasiun A dan stasiun B mendapatkan hasil yang berkisar antara $29,76 \%-30,09 \%$. Teripang yang hidup didalam ekosistem lamun dan terumbu karang juga memiliki kadar toleransi terhadap salinitas. Menurut Sutaman (1992), bahwa salinitas yang baik untuk kehidupan teripang berkisar antara $26-33 \%$.

Kedalaman sangat berhubungan dengan kecerahan perairan. Kedalaman yang tinggi membuat penetrasi cahaya semakin tinggi, faktor ini sangat berhubungan dengan ketersediaan cahaya dan tingkat kecerahan perairan. Kecerahan yang didapatkan pada setiap stasiun yaitu stasiun A dan stasiun B adalah tidak terhingga yang berarti dasar perairan dapat dilihat dari permukaan air laut. Hal ini disebabkan oleh kedalaman yang diperoleh pada lokasi sampling yaitu pada stasiun A berkisar antara 0,60 meter - 1,05 meter, dan pada stasiun B berkisar antara 0,41 meter - 0,85 meter. Kedalaman perairan berpengaruh terhadap tingkat intensitas cahaya matahari yang masuk kedalam suatu perairan. Kecerahan air dipengaruhi oleh intensitas dari matahari, keadaan awan dan kondisi perairan tersebut. Kecerahan perairan berhubungan dengan kesuburan perairan yaitu berlangsungnya kegiatan fotosintesis oleh plankton yang membutuhkan sinar matahari. Kecerahan yang mencapai kedalaman jauh ke dasar perairan memungkinkan masih berlangsungnya kegiatan fotosintesis oleh plankton sampai ke dasar perairan (Saputra, 2001).

Derajat keasaman $(\mathrm{pH})$ air laut yang diperoleh pada stasiun A dan stasiun B berkisar antara 6,58 - 7,05. Nilai pH yang konstan berpengaruh terhadap aktivitas enzim, karena enzim memiliki efisien yang optimum pada nilai pH yang spesifik. Menurut Sutaman (1992), pH air yang cocok untuk teripang antara 7,5 - 8,6. Nilai derajat keasaman yang sama pada semua stasiun penelitian, disebabkan karena $\mathrm{pH}$ air laut biasanya tidak menunjukkan perubahan yang cukup besar dan biasanya cukup stabil karena adanya sistem karbonat dalam air laut (Nybakken, 1992).

Kecepatan arus yang terukur di lokasi penelitian terdapat perbedaan, kecepatan arus yang didapatkan pada stasiun A berkisar antara $0,53 \mathrm{~m} /$ detik hingga $0,72 \mathrm{~m} /$ detik. Sedangkan pada stasiun B berkisar antara 0,49 $\mathrm{m} /$ detik hingga $0,67 \mathrm{~m} /$ detik. Hal ini memperlihatkan bahwa arus lebih mempengaruhi perairan terbuka dibandingkan dengan perairan tertutup. Menurut Mann (1982) dalam Ruswahyuni (2010), perairan terbuka adalah perairan yang tidak terlindung serta dipengaruhi oleh ombak dan gelombang. Akibat dari arus dan gelombang menimbulkan turbulensi pada perairan terbuka dan terjadi pengadukan substrat dasar pada perairan tersebut yang akan mempengaruhi organisme yang terdapat di dalamnya. Menurut Brafield (1978) dalam Ruswahyuni (2010), gerakan ombak merupakan faktor lingkungan yang dominan beraksi di perairan ini, sehingga banyak organisme mengalami kesulitan menyesuaikan diri.

\section{Kesimpulan}

Kesimpulan yang dapat diambil dari penelitian Kelimpahan Teripang di Perairan Terbuka dan Perairan Tertutup Pulau panjang Jepara, Jawa Tengah adalah kelimpahan jenis teripang yang terdapat pada perairan terbuka adalah 109 individu yang terdiri dari $H$. atra dengan jumlah sebanyak 72 individu/1200m ${ }^{2}$, spesies $H$.

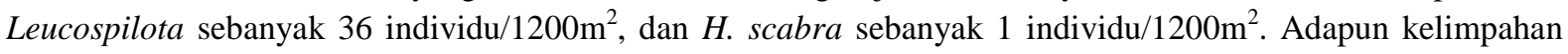
teripang pada perairan tertutup adalah 59 individu yang terdiri dari $H$. atra dengan jumlah sebanyak 37 individu/1200 $\mathrm{m}^{2}$ dan spesies $H$. Leucospilota sebanyak 22 individu/1200m². 


\section{Ucapan Terima Kasih}

Penulis mengucapkan terimakasih kepada Dr. Ir. Bambang Sulardiono, M.Si dan Dr. Ir. Frida Purwanti, M.Sc atas bimbingan dan arahannya dalam penyusunan jurnal ini.

\section{DAFTAR PUSTAKA}

Aziz, A. 1995. Beberapa catatan tentang teripang bangsa Aspidochirotida. Oseana. 20 (4) : $11-23$. 1997. Status penelitian teripang komersial di Indonesia. Oseana. 22 (1) : 9 - 19.

BTNKj (Balai Taman Nasional Karimunjawa). 2008. Laporan Pelaksanaan Kegiatan Pembinaan Habitat Teripang BTNKj. Semarang, $28 \mathrm{hlm}$.

Dinas Pariwisata dan Kebudayaan Jepara. 2011. Your Gateaway to Jepara Tourism. http://www.ticjepara.com/12/pulau-panjang.html (Diunduh tanggal 19 Agustus 2013)

Hyman, L. H. 1995. The Invertebrates : Echinodermata The Coelomnata Bilateria. Vol. IV. Mc.Graw-Hill Book Company. London

Kordi, K.M.G.H. 2010. Ekosistem Terumbu Karang. Rineka Cipta : Jakarta

Nontji, A. 2005. Laut Nusantara. Djambatan : Jakarta

Odum, E. P. 1993. Dasar-dasar Ekologi. Fundamental of Ecology. Gajah Mada University Press. Yogyakarta

Ruswahyuni. 2010. Populasi dan Keanekaragaman Hewan Makrobenthos Pada Perairan Tertutup dan Terbuka di Teluk Awur, Jepara. Jurnal Ilmiah Perikanan dan Kelautan. Vol.2, No1.

Saputra, D. A. 2001. Struktur Komunitas Teripang (Holothuroidea) di Perairan Pantai Pulau Pramuka dan Pulau Tikus Kepulauan Seribu Jakarta. Institut Pertanan Bogor. Bogor

Suprapti, N., H. Sugondo., M. Hadi dan U. Tarwodjo. 1993. Studi Plankton di Sekitar Daerah PLTU. Semarang. $7 \mathrm{hlm}$. (tidak dipublikasikan)

Sutaman. 1992. Petunjuk Praktis Budidaya Teripang. Penerbit Kanisius. Yogyakarta.45 hlm 1993. Petunjuk Praktis Budidaya Teripang. Penerbit Kanisius, Yogyakarta. 1-19 hlm

Wilham, JL. And Dorris, T. C. 1968. Biological Parameter of Water Quality Criteria. Biology Scientific Publication, Oxford. 